\title{
The History of Disaster Incidents and Impacts in Nepal 1900-2005
}

\author{
Komal Raj Aryal* \\ Disaster and Development Centre, Northumbria University, Newcastle NE1 8ST, UK
}

\begin{abstract}
The people of Nepal today are exposed to perennial local disaster events and profound vulnerability to disaster. The combined efforts of government, donors, UN agencies, NGOs, and Nepalese communities are needed to avert the impacts of disaster events. Much more can be done immediately to reduce the impacts by reviewing the scope and distribution of past disaster events. This article provides an overview of Nepal's disaster vulnerability through an analysis of the record of disaster events that occurred from 1900 to 2005. The data were generated from historical archives and divided into incidents at the district, subnational, and national levels. Statistical and Geographical Information System (GIS) analyses were carried out to generate district level disaster vulnerability maps. It is concluded that small-scale, local disasters have a greater cumulative impact in terms of casualties than large-scale, national disasters.
\end{abstract}

Keywords disaster risk, disaster vulnerability, local disasters, Nepal

\section{Introduction}

Nepal is a small landlocked country with an estimated per capita gross domestic product (GDP) of USD 470 in 2008/09 (UNDP 2009) and a population of 29 million people (CBS 2011), some 85 percent of whom are based in rural areas. Administratively, Nepal is divided into five regions: Eastern, Central, Western, Mid-Western, and Far-Western. It is further split into 14 zones and 75 districts.

Nepal's hazard profile, based on DesInventar Disaster Information System (DesInventar 2011), indicates that Nepal is prone to a plethora of natural and human induced calamities. The country's hazards include epidemics, floods, landslides and mudslides, urban and wild fires, glacier lake outbursts, wind storms, cold and heat waves, road accidents, drowning incidents, landmines, and earthquakes (MoHA and DPNet 2009).

Vulnerability to disaster in Nepal is deeply complex and highly variable throughout the country. The incidence of disasters in Nepal is increasing, linked to factors such as weak governance, population growth, rapid urban expansion,

\footnotetext{
* E-mail: k.aryal@northumbria.ac.uk
}

relatively weak land-use planning, the spread of informal settlements, poor construction methods, steep land farming practices, encroachment of settlements into river plain and forest areas, and environmental degradation (Aryal 2012). Recent experiences of the Disaster Management Department of the Nepal Red Cross Society and the Practical Action Nepal Office show the negative impacts of small and localized disaster events on local livelihoods and ecosystems in

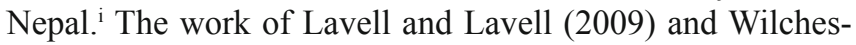
Chaux (2007) on local disaster risk reduction in Latin America highlights the importance of past disaster incidents for current and future local development planning. Climate change appears set to exacerbate the situation, resulting in a higher incidence of droughts, floods, water-induced landslides, and glacier lake outburst floods. This can jeopardize development efforts.

When considering new development, knowledge of risk is of paramount importance. Generation of risk knowledge occurs through a diverse array of channels - disaster history can be one of them. Comprehensive historical disaster impact analysis in Nepal has not been undertaken to date. Learning from the history of disaster events assists academics, policy makers, and emergency responders to address vulnerability to achieve effective disaster response systems in Nepal. Exploring disaster vulnerability in a particular geographical location is an important starting point towards building resilience. This is supported by O'Brien, O'Keefe, and Rose (2008, 521):

A vulnerability perspective outlines the nature of variable exposure to both extremes and long-term change. Fear of fear is valuable insight in human response to produced risks. Vulnerability perspective gives a deeper and more penetrating analysis and provides the departure point for building societal resilience.

This article outlines the results of a disaster history generated by reviewing reported disasters in the National Archives of Nepal in Kathmandu. They are based on reported disasters in the Nepalese national newspaper, Gorkhapatra, ${ }^{\text {ii }}$ from 1900 to 2005. Fewer disaster reports are available from the early twentieth century and information is less detailed than in reports published later. This indicates that, although Nepal has a long history of disaster events, data are limited by the quality and type of information. 
Disaster vulnerability is explored through two types of analysis: (1) a descriptive statistical analysis of disaster vulnerability at district, subnational, and national levels and (2) a Geographical Information System (GIS) based analysis to generate district level disaster vulnerability maps.

\section{Methodology}

Disaster risk vulnerability at district, subnational, and national levels was recorded and analyzed in relation to the number and type of historical disaster events and the number of reported human casualties (1900-2005).

Nepal's political geography has undergone great changes. Prior to the Rana dynasty (1846-1951), Nepal's political and geographical map was divided into three distinct ecological zones: the Mountain, Hill, and Terai. During the Rana regime, Nepal was divided into 20 Hill districts, nine Terai districts, and three inner Terai (also called Bhitri Madesh) districts. The geographical administrative division of Nepal based on the Rana regime ended in 1961 and the country was subsequently divided into 75 districts and 14 zones (CBS 2003). In 1972, the 14 zones were grouped into four development regions. In 1980, this was increased to five development regions: Far-Western, Mid-Western, Western, Central, and Eastern. After the establishment of the multiparty system in April 1990, the zones were no longer regarded as functional administrative units. The spatial distribution of disaster event reporting and the human casualty analysis in this article are focused on ecological zones, development regions, and districts.

The shape file was adapted from ICIMOD (2000) Nepal base file. The fields, which represent each disaster type for total human casualties, were recorded and total reporting of recorded disaster types per district was used to generate six new fields. Each field is representative of the final data displayed on each relevant map. For example, to create the data to show total human casualties caused by epidemics versus total reporting of epidemic events between 1900 and 2005, the field for total number of deaths recorded for epidemics per district was divided by the total number of epidemics recorded per district. Data interpretation is conducted through GIS-based maps. The main objective of these maps is to illustrate the distribution of vulnerability across Nepal.

The historical disaster data generation process is shown in Figure 1. The following steps were carried out to generate disaster data from the historical archives:

(1) Reported disaster news was divided based on geographical locations (based on districts).

(2) Disasters were divided into five hazard groups:

- Epidemics ${ }^{\mathrm{iii}}$ : cholera, dysentery, dengue fever, and Japanese encephalitis are the major diseases;

- Storms: thunderstorms, hailstorms, snowstorms, and windstorms;

- Floods: floods and heavy rains;
- Landslides: mudslides, debris flows, landslides, glacier lake outburst floods, and avalanches;

- Fires: house fires, forest fires, and industrial fires.

(3) The five hazard groups ${ }^{\text {iv }}$ were converted to numerical data in an XL file. From the XL file, historical disaster data were analyzed statistically. The file was converted to a .dbf file in the GIS system to produce disaster vulnerability maps based on reported data as shown in Figure 2.

\section{Limitations}

The quantitative data were collected from newspaper articles. These data are often less detailed than would be ideal and the accuracy of the reporting can be questionable. It is possible that small disasters or disasters with human impact at the lower end of the scale may not have made sufficient impact to ensure that they were reported in the national press, and for that reason it is possible that the reported figures for smallscale disasters are lower than reality. It is also accepted that more recent reporting is likely to be more rigorous than that in earlier years, as is the case for disaster reporting globally.

Despite the significant threat that earthquakes present in the Himalayan region, there has been a prolonged seismic gap in major earthquake events over the last century. Large-scale earthquake impacts are therefore not considered in this study although the general consensus is that a large earthquake is "overdue" in Nepal (NSET Nepal 2008).

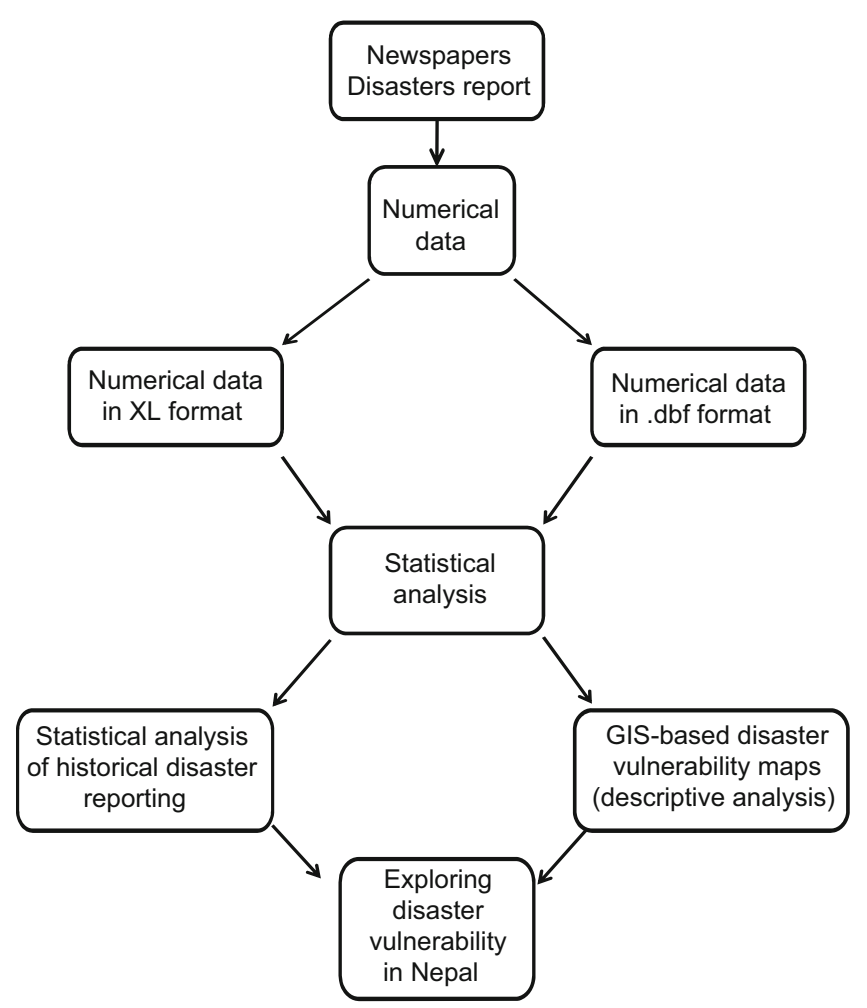

Figure 1. Historical disaster data generation and analysis process 

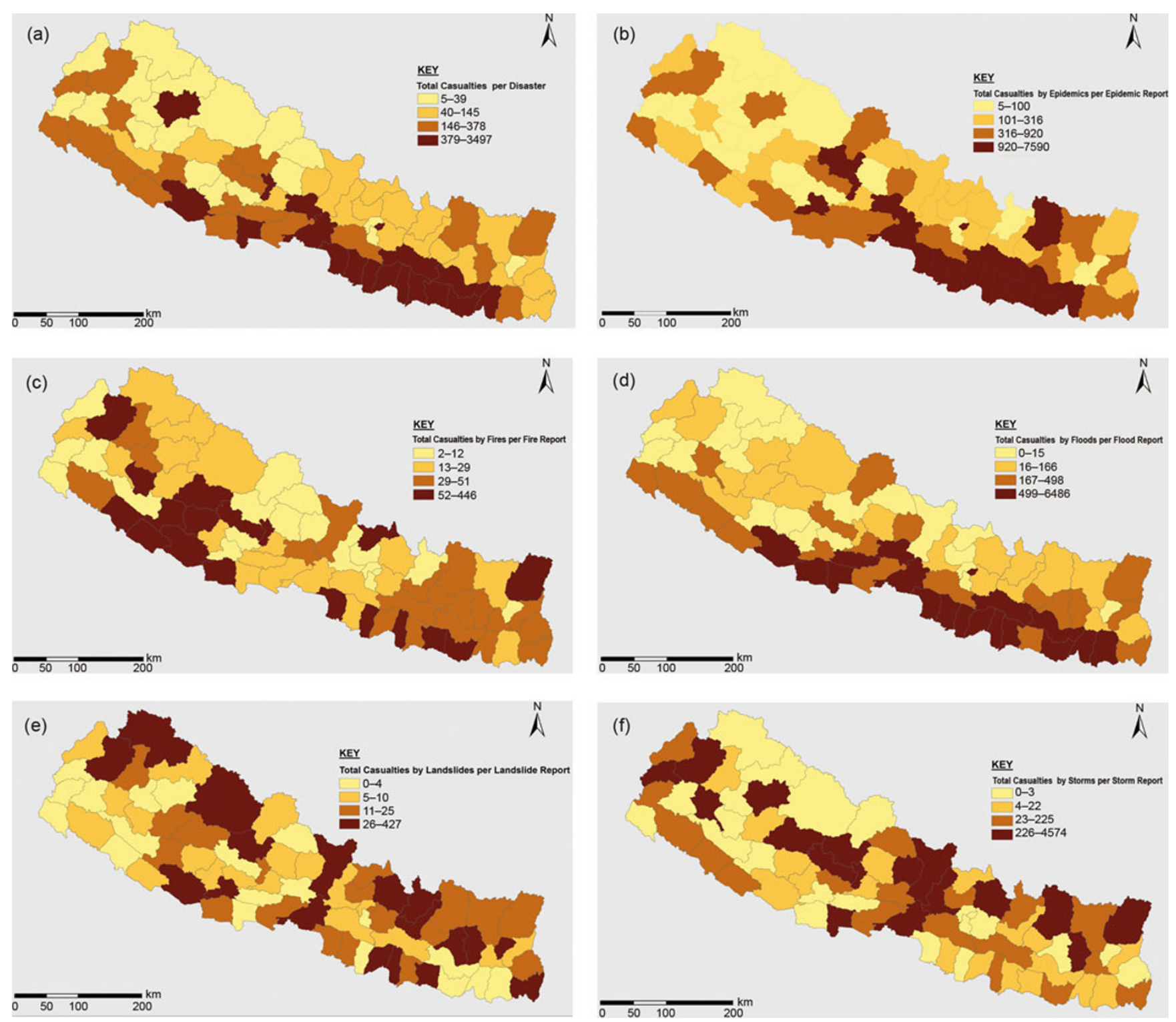

Figure 2. Disaster vulnerability maps of Nepal, 1900-2005: Total casualties per disaster reported (a); Total casualties caused by epidemics per epidemics reported (b); Total casualties caused by fires per fire reported (c); Total casualties caused by floods per flood reported (d); Total casualties caused by landslides per landslide reported (e); Total casualties caused by storms per storm reported (f)

\section{Statistical Analyses}

This section describes the reported disaster incidents of Nepal in Gorkhapatra daily through descriptive statistical analyses.

\subsection{Dispersal of Disaster Reporting and Human Casualties}

People gravitate towards areas with high-potential land. This creates pressure on the environment, which can then precipitate environmental disasters. For example, many landslides are increasingly caused by inappropriate agricultural practices on steep slopes (Adhikari 2000). The geographical distribution of disaster events and human casualty reports are inexorably linked as human activity ultimately impacts the physical environment. There is a greater likelihood of disasters occurring in populated areas, particularly in areas with agricultural production. Frequency of disasters may be influenced by combinations of social-cultural, economic, environmental, historical, and developmental factors. Together, these factors contribute to migration, change of population density and distribution, and may be further influenced by local knowledge regarding the best locations for living.

\subsection{Changes in Reported Disaster Events and Human Casualties Nationwide}

To illustrate the linkages between human activity and disasters, Table 1 shows the total number of reported disaster 
events and human casualties occurring every ten years from 1900 to 2005 . Table 2 illustrates the average percentage of human casualties during each ten-year period.

Even allowing for some fluctuation in reporting practice, Table 1 shows that reported human casualties declined in the 1950s and then steadily increased into the twenty-first century. Reasons for the only modest increase in disaster reporting in the 1950s are unknown. The huge increase in human casualties evident in the 1960s when compared to reporting for earlier periods is likely to have resulted from the catastrophic worldwide influenza epidemic. ${ }^{v}$

\subsection{Disaster Events by Ecological Zones}

Geographically, the country is divided into three ecological zones: Mountain, Hill, and Terai. Ecological zones are defined by prevailing climatic conditions, the variation of agricultural land, and other resources. Disaster events recorded from 1900 to 2005 are shown in Table 3. The table shows that the highest number of disaster events was recorded in the Hill area, which covers 56.2 percent of Nepal's total land mass, but that the highest number of casualties occurred in the Terai area. This is accounted for by the high rates of flood and disease in that area. Among the total reported disaster events in the Hill area, epidemics were reported 1353 times, accounting for 21.6 percent of total reported disasters in the Hill area. Fires were reported 1916 times (30.7 percent of all reported disasters in the Hill area), floods 903 times (14.4\%), storms 473 times (7.6\%), and there were 1610 incidents of landslides $(25.7 \%)$.

Terai areas showed the second highest number of recorded disaster events. There were 5690 disaster events reported in the Terai, which covers 20.1 percent of the total land area of Nepal. Among the total reported events in the Terai, fires were reported 2139 times $(37.6 \%)$, followed by floods 1674 times (29.4\%), epidemics 1416 times (24.9\%), storms 348 times (6.1\%), and landslides 113 times (1.9\%).

Mountain zones cover 23.7 percent of the total land mass of Nepal with a recorded number of 1580 disaster events. Landslides were reported 555 times (35.1\%), epidemics 362 times $(22.9 \%)$, fires 321 times $(20.3 \%)$, storms 179 times (11.3\%), and floods 163 times (10.3\%). Landslides, epidemics, and fires were the dominant three hazards that affected the livelihoods of the mountain regions.

\subsection{Human Casualties in Disasters by Ecological Zones}

When the number of human casualties is analyzed using reported disaster events, the Terai has the highest number of human casualties $(6,040,168)$ of the three ecological zones. Of the total number of reported human casualties, 3,024,594 (50.1\%) were caused by epidemics, $2,856,193(47.3 \%)$ by floods, 126,848 (2.1\%) by fires, $18,307(0.3 \%)$ by storms, and $14,226(0.2 \%)$ by landslides.

Table 1. Total number of reported disaster events, human casualties, and annual change in Nepal, 1900-2005

\begin{tabular}{|c|c|c|c|c|c|c|}
\hline Year & $\begin{array}{c}\text { Total Disasters } \\
\text { Reported } \\
\text { per Period }\end{array}$ & $\begin{array}{c}\text { Change in Disaster } \\
\text { Reporting Every } \\
\text { Ten Years }\end{array}$ & $\begin{array}{l}\text { Annual Change in } \\
\text { Rate of Disaster } \\
\text { Reporting }\end{array}$ & $\begin{array}{c}\text { Human Casualties } \\
\text { Reported } \\
\text { per Period }\end{array}$ & $\begin{array}{l}\text { Change in Human } \\
\text { Casualties Reporting } \\
\text { Every Ten Years }\end{array}$ & $\begin{array}{l}\text { Annual Change in } \\
\text { Rate of Human } \\
\text { Casualty Reporting }\end{array}$ \\
\hline 1900-09 & 22 & & & 156 & & \\
\hline 1910-19 & 53 & +31 & 5.84 & 691 & 535 & 8.0 \\
\hline $1920-29$ & 189 & +136 & 7.19 & 1703 & 1012 & 6.0 \\
\hline $1930-39$ & 324 & +135 & 4.16 & 2445 & 742 & 3.0 \\
\hline $1940-49$ & 565 & +241 & 4.26 & 24,334 & 21,889 & 9.0 \\
\hline $1950-59$ & 582 & +17 & 0.29 & 17,865 & -6469 & -3.6 \\
\hline $1960-69$ & 691 & +109 & 1.57 & 79,784 & 61,919 & 7.8 \\
\hline $1970-79$ & 1516 & +825 & 5.44 & 240,186 & 160,402 & 6.7 \\
\hline $1980-89$ & 2032 & +516 & 2.53 & $1,372,841$ & $1,132,655$ & 8.2 \\
\hline 1990-99 & 4039 & +2007 & 4.96 & $4,000,768$ & $2,627,927$ & 6.5 \\
\hline $2000-05$ & 3512 & Not available & Not available & $1,666,123$ & Not available & Not available \\
\hline
\end{tabular}

Table 2. Human casualties in percent of total population in Nepal, 1900-2005

\begin{tabular}{|c|c|c|c|c|}
\hline Year & $\begin{array}{l}\text { Reported Human } \\
\text { Casualties }\end{array}$ & Census Year & Population $^{\dagger}$ & $\begin{array}{c}\text { Human Casualties Every Ten Years } \\
\text { as } \% \text { of Population }\end{array}$ \\
\hline 1900-09 & 156 & & & \\
\hline 1910-19 & 691 & 1911 & $5,638,749$ & 0.01 \\
\hline $1920-29$ & 1703 & 1920 & $5,573,788$ & 0.03 \\
\hline $1930-39$ & 2445 & 1930 & $5,532,574$ & 0.04 \\
\hline $1940-49$ & 24,334 & 1940 & $6,283,649$ & 0.40 \\
\hline $1950-59$ & 17,865 & 1950 & $8,256,625$ & 0.20 \\
\hline $1960-69$ & 79,784 & 1961 & $9,412,996$ & 0.80 \\
\hline $1970-79$ & 240,186 & 1971 & $11,555,983$ & 2.00 \\
\hline $1980-89$ & $1,372,841$ & 1981 & $15,022,839$ & 9.10 \\
\hline 1990-99 & $4,000,768$ & 1991 & $18,491,097$ & 21.60 \\
\hline $2000-05$ & $1,666,123$ & 2001 & $23,151,423$ & Not available \\
\hline
\end{tabular}

†Source: CBS 2003. 
Table 3. Distribution of human casualties by disasters and ecological zones in Nepal, 1900-2005

\begin{tabular}{|c|c|c|c|c|c|c|c|}
\hline & & Mountain & $\begin{array}{l}\% \text { of All Events } \\
\text { or Casualties }\end{array}$ & Hill & $\begin{array}{c}\% \text { of All Events } \\
\text { or Casualties }\end{array}$ & Terai & $\begin{array}{c}\% \text { of All Events } \\
\text { or Casualties }\end{array}$ \\
\hline \multirow[t]{2}{*}{ Epidemics } & Events & 362 & 2.60 & 1353 & 10.00 & 1416 & 10.46 \\
\hline & Casualties & 103,483 & 1.39 & 585,941 & 7.91 & $3,024,594$ & 40.83 \\
\hline \multirow[t]{2}{*}{ Fires } & Events & 321 & 2.37 & 1916 & 14.49 & 2139 & 15.81 \\
\hline & Casualties & 8919 & 0.12 & 54,931 & 0.74 & 126,848 & 1.71 \\
\hline \multirow[t]{2}{*}{ Floods } & Events & 163 & 1.23 & 903 & 6.67 & 1674 & 12.37 \\
\hline & Casualties & 9344 & 0.12 & 388,745 & 5.24 & $2,856,193$ & 38.56 \\
\hline \multirow[t]{2}{*}{ Landslides } & Events & 555 & 4.10 & 1610 & 11.90 & 113 & 0.83 \\
\hline & Casualties & 14,397 & 0.19 & 31,610 & 0.42 & 14,226 & 0.19 \\
\hline \multirow[t]{2}{*}{ Storms } & Events & 179 & 1.32 & 473 & 3.49 & 348 & 2.57 \\
\hline & Casualties & 68,369 & 0.92 & 100,857 & 1.36 & 18,307 & 0.24 \\
\hline \multirow[t]{2}{*}{ All } & Events & 1580 & 11.62 & 6255 & 46.55 & 5690 & 41.84 \\
\hline & Casualties & 204,512 & 2.74 & $1,162,084$ & 15.67 & $6,040,168$ & 81.53 \\
\hline
\end{tabular}

In the past 60 years, settlement of disaster refugees from the Hill and Mountain zones has increased the rates of deforestation in the Terai (Shrestha 2001). This immigration exacerbated the overexploitation of local environmental resources, particularly as a result of inappropriate agricultural production and house building, coupled with excessive deforestation causing land degradation and heightened exposure to risk. $^{\text {vi }}$

In the Hill area, 1,162,084 human casualties were reported between 1900 and 2005. Among the human casualties, 585,941 (50.4\%) were caused by epidemics, 388,745 (33.4\%) were due to fires, 100,857 (8.7\%) resulted from storms, $54,931(4.7 \%)$ were a result of floods, and 31,610 (2.7\%) were caused by landslides.

In the Mountain zone, 204,512 human casualties were recorded. Among the human casualties reported in mountain zones, 103,483 (50.5\%) resulted from epidemics, 68,369 (33.4\%) from storms, 14,397 (7.0\%) from landslides, 9344 (4.6\%) from floods, and 8919 (4.4\%) from fires.

According to the historical data, 81.5 percent of the total reported human casualties occurred in the Terai region, whereas Hill and Mountain areas accounted for about 15.7 percent and 2.8 percent of total human casualties respectively. This confirms that the Terai regions are more vulnerable to disasters.

\subsection{Disaster Events Recorded by Development Regions}

The disaster events recorded by development regions in Nepal are shown in Figure 3. The Central and Eastern development regions experienced high numbers of disaster events (5039 and 3235 respectively) and account for 37.2 percent and 23.9 percent of the total disaster events recorded. Total disaster events recorded in the Western, Mid-Western, and Far-Western development regions are 18.4 percent, 12.4 percent, and 7.8 percent respectively.

\subsection{Human Casualties Recorded by Development Regions}

Disaster casualties by development regions are also shown in Figure 3. The Central development region accounts for the highest number of human casualties, whereas the Far-Western region accounts for the lowest number. The Central and FarWestern regions each contribute 65.3 percent and 2.3 percent to the total recorded number of human casualties in Nepal between 1900 and 2005. An annual average number of 50,708 human casualties were calculated from the available data for the Western region, 46,042 for the Central region, 13,885 for the Eastern region, 3308 for the Mid-Western region, and 1599 for the Far-Western region. Figure 3 also illustrates the average number of human casualties per year for this period of time (1900-2005).

\section{Rate of Growth of Human Casualties}

This section outlines the growth in disaster induced human casualties in different ecological zones, development regions,

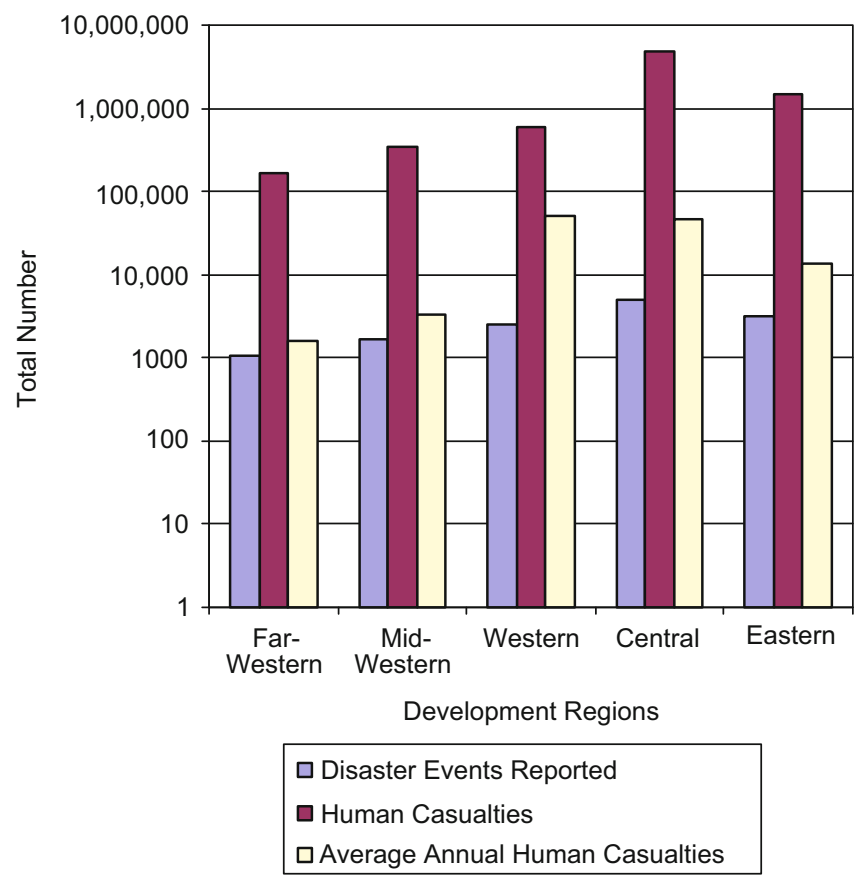

Figure 3. Disaster events, total human casualties, and average annual human casualties by development regions in Nepal, 1900-2005 
and districts of Nepal. Since disaster distribution is not strictly comparable by district until 1983, the growth rate is calculated through the number of total human casualties by disaster between 1990 and 1999 and data from the population census of 2001.

\subsection{Growth in Human Casualties by Ecological Zones}

Growth rates of human disaster casualties by ecological zones are presented in Table 4. An examination of the data contained in this table indicates that the overall disaster-induced human casualties have a greater impact in the Terai area than in the Mountain and Hill zones.

\subsection{Human Disaster Casualty Growth Rate by Development Regions}

Table 4 shows that during the period 1990 to 1999 , of the mountainous areas, four development regions have human casualty growth rates of less than one percent, highlighting that the mountain areas of the Mid-Western development region have the highest human casualty growth rate $(1.59 \%)$. In the Hill areas, four development regions have an annual human casualty growth rate of less than one percent, while the Eastern region has the recorded highest human casualty growth rate of 6.04 percent. Of the Terai areas, only the FarWestern development region has a human casualty growth rate of less than one percent. Other Terai areas show annual human casualty growth rates of between 1.15 percent in the Mid-Western development region and 5.17 percent in the Western development region. These data appear to show that for the period 1990 to 1999, it would have been safest to live in the Mountain or Hill areas, with the exception of the Eastern Hill development region, whereas the Terai areas should have been avoided if possible, except for the Far-Western parts of the Terai. This demonstrates the worsening disaster situation in the Terai areas.

\subsection{Human Disaster Casualty Growth Rate by District}

In Nepal, the village development committees and/or municipal wards are the lowest administrative units, and the district administrative unit functions as a coordinating administrative unit to formulate, execute, and evaluate the plans and administrative work of the lower administrative units. Therefore, it is appropriate to examine human casualties by districts.

Table 4. Annual growth rate of human casualties by ecological and development regions in Nepal, 1990-1999

\begin{tabular}{lccc}
\hline $\begin{array}{l}\text { Development } \\
\text { Regions }\end{array}$ & $\begin{array}{c}\text { Mountain } \\
\text { (\%) }\end{array}$ & $\begin{array}{l}\text { Hill } \\
\mathbf{( \% )}\end{array}$ & $\begin{array}{l}\text { Terai } \\
\mathbf{( \% )}\end{array}$ \\
\hline Far-Western & 0.59 & 0.50 & 0.39 \\
Mid-Western & 1.59 & 0.29 & 1.15 \\
Western & 0.72 & 0.47 & 5.17 \\
Central & 0.37 & 0.67 & 3.90 \\
Eastern & 0.06 & 6.04 & 1.54 \\
\hline
\end{tabular}

Since 1971, the number of districts has remained constant at 75 . However, there were great changes in area size and boundaries between 1971 and 1982. Disaster distribution is not strictly comparable by district until 1983 .

The Geographical Information Systems based maps shown in Figure 2 have been used to assist this process. The data produced from this extensive exercise have been presented to government ministers, disaster practitioners, and experts in Nepal and at other international events. They cannot be presented with one hundred percent confidence as coverage of all disaster events, but have raised important issues in terms of predisaster planning.

Human casualties from disasters are spread throughout the districts of Nepal. However, wide variation is observed in disaster casualty growth rates among the districts. The results show that 14 of the 75 districts of Nepal have a higher than two percent annual human casualty growth rate. Nine out of the 14 have a growth rate of three percent, and five districts have a human casualty growth rate of four percent per year. The five districts with the highest annual human casualty growth rates are Parsa (6.3\%), Mahottarai (5.8\%), and Dhanusa (5.5\%) in Central Terai, Saptari (5.9\%) in Eastern Terai, and Lamjung (5.3\%) in Western Terai.

The 12 districts with the lowest average annual human casualty growth rates (less than $0.1 \%$ ) are Dolpa $(0.01 \%)$ in the Mid-Western Mountain area, Pyuthan $(0.08 \%)$ in the MidWestern Hill area, Rasuwa (0.08\%) in the Central Mountain region, Manang $(0.08 \%)$ in the Western Mountain region, Ilam $(0.08 \%)$ in the Eastern Hill region, Kalikot $(0.07 \%)$ in the Mid-Western Mountain region, Darchula $(0.07 \%)$ in the Far-Western Mountains, Kaski $(0.06 \%)$ and Arghakanchi $(0.05 \%)$ in the Western Hill region, and Lalitpur $(0.06 \%)$ and Kathmandu (0.04\%) in the Central Hills.

Human disaster casualty growth rates in all mountainous districts vary between 0.01 and 2.0 percent per annum except in Jumla $(4.8 \%)$. This indicates a significantly wide variation of disaster casualty growth for the mountainous areas of Nepal. Similarly in the Hills, the growth rates of human casualties from disasters vary between an annual rate of 0.06 percent and 5.3 percent in most districts. Three Hill districts in Nepal have annual growth rates of disaster casualties from 3.0 percent to 5.3 percent. In the Terai areas, human casualty growth rates vary between 0.1 percent and 6.3 percent per annum. However, one district has a human casualty growth rate of less than 0.1 percent while six districts have human casualty growth rates of 3.0 percent to 6.3 percent per annum.

Table 5 shows that two-thirds of Nepal's districts have human disaster casualty growth rates of less than one percent. Among the 75 districts of Nepal, five districts have a human casualty growth rate of 1.0 to 1.9 percent, four districts are in the range of 2.0 to 2.9 percent, four districts are between 3.0 and 3.9 percent, one district is in the range of 4.0 to 4.9 percent, and five districts are above five percent. Eight out of 19 districts in the Central development region have annual disaster casualty growth rates of 2.0 to 6.3 percent. This spatial variation relates to the influence of rapid urban development on disaster vulnerability in Nepal. 


\section{Density of Disaster Events and Human Casualties}

In this article the density of disaster events is defined as the number of disaster events per square kilometer, that is, Disaster Event Density $($ DED) $=$ Number of Disaster Events / Area $\left(\mathrm{km}^{2}\right)$. Similarly, the human casualty density is defined as the number of human casualties resulting from disasters per square kilometer, that is, Human Casualty Density $(\mathrm{HCD})=$ Number of Casualties by Disaster Events / Area $\left(\mathrm{km}^{2}\right)$.

Disaster event density can tell us locational exposure to disasters whereas the history of human casualties is an effective indicator for measuring vulnerability to disasters. The disaster casualty density by ecological zones, development regions, and districts is presented below.

\subsection{Disaster Casualty Density by Ecological Zones}

Disaster casualty density is highest in the Terai areas. This could be due to the pressures on environmental resources in the Terai and the population density in this region. Since the successful control of malaria in the Terai in the 1960s, migratory movements from the hill and mountain areas to the Terai plain have increased. The growth of population in the Terai region is one of the visible changes brought about by internal migration. The attraction of the Terai could be resettlement programmes, availability of energy resources (woods), the fertile arable land, employment opportunities, and better communication and transport facilities linked to India. Figure 4 illustrates that the Terai areas, except for the FarWestern Terai, have a significantly higher disaster casualty density than the Mountain and Hill areas.

\subsection{Disaster Casualty Density by Development Regions}

The disaster casualty density is highest in the Central development regions and lowest in the Mid-Western and FarWestern regions. The Far-Western Terai has a lower disaster casualty density than the Eastern Hill area. Similarly, the Western Mountain area has a lower disaster casualty density in comparison to other development regions. The number of human casualties per square kilometer in the Central Hills is higher than that of the Western, Mid-Western, and Far-Western Terai regions.

\subsection{Disaster Casualty Density by Districts}

For the 1990-1999 period, Mahottari has the highest number of human disaster casualties per square kilometer, followed by Dhanusa, Saptari, and Parsa. The four highest disaster casualty density districts fall in the Terai plains of Nepal. Most of the mountainous districts have less than one human casualty per square kilometer with the exception of the Eastern mountainous districts and Jumla, where human casualty density is 17. Solukhumbu district, where Mount Everest is located, has a human casualty density of four.

\section{Discussions and Conclusion}

From 1900 to 2005, over 13,000 disaster events were recorded with a total of 7,400,000 human casualties in Nepal. ${ }^{\text {vii }}$ When the number of human casualties from reported disaster events is examined, the Terai has the highest number of human casualties (more than 6,000,000) of the three ecological zones. The Central development region accounts for a high number of human casualties whereas the Far-Western development region accounts for only a low number of total human casualties. Mountainous areas exhibit the lowest number of human casualties by disaster per square kilometer.

The first broad conclusion is that there is significant spatial variation in disaster history in Nepal. This is largely explained by ecological variations across the country. The historical data also show that localized small-scale disasters collectively are having a greater impact upon society in terms of casualties than national large-scale disasters in Nepal. In July 1993, a single national disaster event (flood and landslides) affected six districts of Nepal (Dhading, Makwanpur, Rautahat, Sarlahi, Sindhuli, and Chitwan) with 1728 deaths and injured. It received impressive media attention as well as international relief support. However, from the data collected in this research, on average more than 10,000 casualties have occurred every year since 1900 in the same six districts. This shows the importance of the cumulative impact of small-scale disasters for lives and livelihood security in Nepal. Also "small scale events which are often repetitive and chronic are of more concern to local communities. A range of small scale hazards (floods, landslides, fire, diseases, impact of high wind) erode the meaning of subsistence of already marginalised farmers" (Gaillard et al. 2010, 68). Secondly, disaster

Table 5. Range of district level human casualty growth rates by development regions in Nepal, 1990-1999

\begin{tabular}{|c|c|c|c|c|c|}
\hline $\begin{array}{l}\text { Human Casualty Growth } \\
\text { Rate \% per Annum } \\
\text { (Average) }\end{array}$ & $\begin{array}{c}\text { Far-Western } \\
\text { Development Region } \\
\text { (FWDR) }\end{array}$ & $\begin{array}{c}\text { Mid-Western } \\
\text { Development Region } \\
\text { (MWDR) }\end{array}$ & $\begin{array}{c}\text { Western } \\
\text { Development Region } \\
\text { (WDR) }\end{array}$ & $\begin{array}{c}\text { Central } \\
\text { Development Region } \\
\text { (CDR) }\end{array}$ & $\begin{array}{c}\text { Eastern } \\
\text { Development Region } \\
\text { (EDR) }\end{array}$ \\
\hline$<1$ & 8 & 13 & 13 & 11 & 11 \\
\hline $1.00-1.99$ & 1 & & & & 4 \\
\hline $2.00-2.99$ & & 1 & 1 & 2 & \\
\hline $3.00-3.99$ & & & 1 & 3 & \\
\hline $4.00-4.99$ & & 1 & & & \\
\hline$>5$ & & & 1 & 3 & 1 \\
\hline Total number of districts & 9 & 15 & 16 & 19 & 16 \\
\hline
\end{tabular}




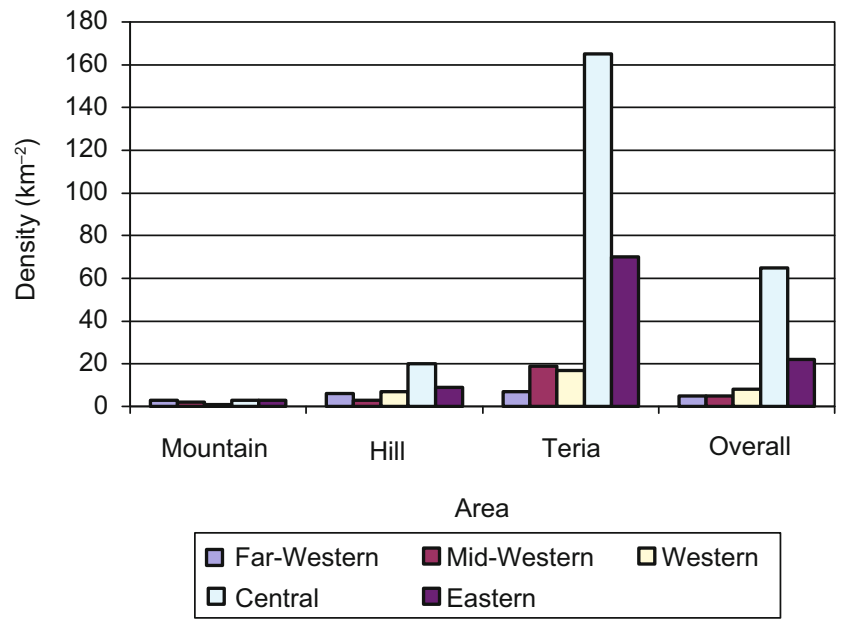

Figure 4. Disaster casualty density by ecological zones and development regions in Nepal, 1990-1999

casualty density is higher in the Terai and the Western and Central areas. Thirdly, the intensity of disasters is increasing in the Terai and the Western and Central areas of Nepal, demonstrated by the Koshi flood in 2008 and the Far-Western and Central Terai floods in 2006, 2007, 2008, and 2012.

Nepal's economy is dependent on rural agricultural activities. Every year the annual budget and key policy strategies emphasize the role of agriculture in poverty reduction in Nepal. Agricultural production mainly takes place in the Terai region. This area is extremely vulnerable to various hazards, namely floods, fires, storms, and heat and cold waves. Visualization methods such as mapping with geographical representation may help decision-makers to adapt their ideas to a changing environment. Disaster impact mapping and statistical analysis in this research indicate that it would be wise to anticipate generalized food scarcity in Nepal in the future. Local, small-scale disasters are of paramount importance and relevance to those living in disaster-prone areas.

Historical disaster data play an important role in the analysis of vulnerability and susceptibility to disasters in any specified location. National disaster risk management strategies, plans, and policies should be formulated based on past local and small-scale disaster impacts in Nepal. The review of past disasters not only shows Nepal's vulnerability but points out the need to plan appropriate local disaster risk management activities. In planning for the future local disaster risk management must take into account past disaster events. In order to devise a reasonable estimate of the nature and extent of disasters in the future, it is necessary to factor in estimates of the impact of past events.

\section{Acknowledgment}

The author thanks Professor Phil O'Keefe, Dr. Andrew Collins, and Dr. Bernard Manyena for their initial comments.

\section{Notes}

i Based on discussion with Mona Devkota from the Nepal Red Cross Society and Mr. Anup Phaiju from the Practical Action Nepal Office at Kathmandu in July 2012.

ii Gorkhapatra is the oldest national daily newspaper of Nepal. It was first published in the summer of 1898 (called Sudha Sagar but changed the name to Gorkhapatra Weekly in May 1901). The Gorkhapatra started daily publication from 1961. Past issues of the newspaper are preserved in the National Archives of Nepal in Kathmandu.

iii Epidemics have been included in this research as they can often be directly linked to disaster events. Floods, for example, can lead to outbreaks of cholera, dysentery, and dengue fever.

iv The five hazard groups are selected in this study due to lack of continuous data for specific disasters (such as cholera, hailstorms, or house fires). The five hazard groups can satisfy the requirement for illustrative vulnerability maps using GIS.

v Based on an informal interview in June 2008 with Dr. D. N. Regmi, one of the longest-serving child specialists of Nepal.

vi The author worked as an environmental officer for five years (19952000) and witnessed these processes in the Terai firsthand.

vii These data were collected, collated, and analyzed as part of the author's Ph.D. dissertation research.

\section{References}

Adhikari, J. 2000. Decisions for Survival Farm Management Strategies in the Middle Hills of Nepal. Delhi: Adroit Publishers.

Aryal, K. R. 2012. Getting Down to Local Level: Exploring Vulnerability to Improve Disaster Management Systems in Nepal. Ph.D. Thesis. Newcastle Upon Tyne: Northumbria University.

CBS (Central Bureau of Statistics). 2003. District of Nepal Indicators of Development. Kathmandu: Central Bureau of Statistics and International Centre for Integrated Mountain Development (ICIMOD).

2011. Preliminary Result of National Population Census 2011. 12 February 2012. http://census.gov.np/ (in Nepalese).

DesInventar. 2011. Nepal. http://www.desinventar.net/DesInventar/ profiletab.jsp? countrycode $=$ np.

Gaillard, J. C., B. Wisner, D. Benouar, T. Cannon, C.-C. Lawrence, J. Dekens, M. Fordham, C. Gilbert, et al. 2010. Alternatives for Sustained Disaster Risk Reduction. Human Geography 3 (1): 66-88.

ICIMOD (International Centre for Integrated Mountain Development). 2000. GIS for Beginners Introductory GIS Concepts and Hand-on Exercises. Kathmandu: ICIMOD.

Lavell, A., and C. Lavell. 2009. Local Disaster Risk Reduction: Lessons from the Andes. Lima: Comunidad Andina.

MoHA (Ministry of Home Affairs) and DPNet (National Disaster Preparedness Network-Nepal). 2009. National Disaster Report 2009: The Hazards and Vulnerability. Kathmandu: Ministry of Home Affairs (MoHA) and National Disaster Preparedness NetworkNepal (DPNet).

UNDP (United Nations Development Programme). 2009. National Human Development Report 2009: Transformation and Human Development. Kathmandu: United Nations Development Programme.

NSET Nepal (National Society for Earthquake Technology-Nepal). 2008. United Nations International Strategy for Disaster Reduction: Global Assessment Report on Poverty and Disaster Risk 2009: Global Assessment of Risk-Nepal Country Report (Final Draft). Kathmandu: NSET Nepal.

O'Brien, G., P. O'Keefe, and J. Rose. 2008. The Vulnerable Society. Area 40 (4): 520-21.

Shrestha, N. R. 2001. The Political Economy of Land, Landlessness and Migration in Nepal. New Delhi: Nirala Publication.

Wilches-Chaux, G. 2007. ENSOWHAT ?: LA RED Guide to Getting Radical with Enso Risks. Bogota: ARFO Editores e Impresores.

Open Access This article is distributed under the terms of the Creative Commons Attribution License which permits any use, distribution, and reproduction in any medium, provided the original author(s) and source are credited. 